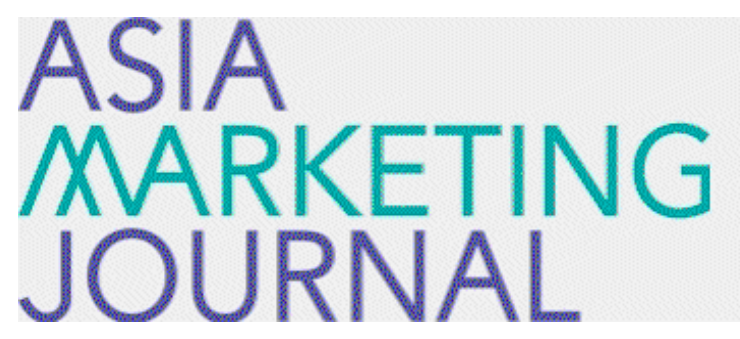

ASIA MARKETING JOURNAL

Volume 13 | Issue 1

Article 2

4-30-2011

\title{
제휴 프로모션에 관한 탐색적 연구
}

\section{Eun Mi Lee}

Hyun Hee Park

Jung Ok Jeon

Follow this and additional works at: https://amj.kma.re.kr/journal

Part of the Marketing Commons

\section{Recommended Citation}

Lee, Eun Mi; Park, Hyun Hee; and Jeon, Jung Ok (2011) "제휴 프로모션에 관한 탐색적 연구," Asia Marketing Journal: Vol. 13 : Iss. 1 , Article 2.

Available at: https://doi.org/10.53728/2765-6500.1276

This Article is brought to you for free and open access by Asia Marketing Journal. It has been accepted for inclusion in Asia Marketing Journal by an authorized editor of Asia Marketing Journal. 


\title{
제휴 프로모션에 관한 탐색적 연구
}

\section{An Exploratory Study on Tie-in Promotion}

\author{
이 은 미(Lee, Eun Mi)* \\ 박 현 희(Park, Hyun Hee)** \\ 전 중 옥(Jeon, Jung $\mathrm{Ok}) * * *$
}

본 연구는 현재 업계에서 진행하고 있는 다양한 형태의 제휴 프로모션 현황을 분석하여 제휴 프 로모션 수단의 개념을 정의하고, 심층면접법을 통해 제휴 프로모션에 대한 소비자의 인식을 확인 하고자 하였다.

연구결과는 다음과 같이 요약할 수 있다. 첫째, 사례분석을 통해 제휴 프로모션 수단을 제휴 가 격할인, 제휴 쿠폰, 제휴 회원제도, 제휴 콘테스트, 제휴 경품, 제휴 프리미엄(유·무형), 제휴 지불 조건, 제휴 샘플, 제휴 이벤트(문화이벤트, 자선이벤트, 체험이벤트), 제휴 리펀드.리베이트로 체계 화 시키고, 각 수단에 대한 개념을 정의함으로써 기존의 판촉수단과 제휴 프로모션 수단의 개념을 구분하고자 하였다.

둘째, 제휴 프로모션에 대한 소비자의 인식을 조사하고, 수집된 자료를 분석하기 위해 Nvivo 8 을 이용하여 확보된 질적 자료를 처리하였다. 분석결과, 제휴 프로모션에 대한 소비자의 인식은 크 게 '선호하는 제휴 프로모션의 특성', '제휴 프로모션의 기대혜택', '제휴 프로모션의 위험요소' 측면 의 총 세 가지 주요 범주로 나누어졌다. 특히, 세 가지 범주 중에서 선호하는 제휴 프로모션의 특 성 범주에 속하는 제휴 프로모션과 자아추구혜택 적합성이라는 요인이 도출된 것은 매우 흥미로운 결과이다.

본 연구의 시사점은 기존 연구에서 기업간 전략적 제휴의 제한적 영역에서만 다루어졌던 제휴 프로모션에 관한 연구를 소비자 관점으로 확대하여 그 연구의 범위를 확장하고, 이와 같은 연구결 과를 기반으로 제휴 프로모션의 유형을 구분하기 위한 향후 연구의 초석을 마련하였다는 점에 있 다.

핵심개념: 제휴 프로모션, 제휴 프로모션 수단, 제휴 프로모션 수단의 개념정의, 제휴 프로모션 수 단에 대한 소비자 인식

* 부경대학교 대학원 경영학과 박사과정 수료

** 경북대학교 경영학부 BK21 연구교수

*** 부경대학교 경영학부 교수(교신저자) 


\section{I. 서 론}

최근 소비자의 개성화와 다양화, 마케팅 커뮤 니케이션 수단의 고도화 등으로 인해 광고효과 의 감소와 함께 광고 비중의 정체성이 두드러 지고 있다. 이에 비해 기업의 판촉비 증가, 판 촉 매체의 발달, 소비자 데이터 이용 가능성의 증가 등으로 판촉활동이 보다 용이하게 되어, 판매촉진은 더 이상 기업의 여타 마케팅 활동 을 보조하는 역할을 넘어 기업의 성과와 소비 자와의 커뮤니케이션에 직접적으로 빠르게 영 향을 미치는 요소로서 가장 주목받고 있는 마 케팅 수단이 되고 있다(김주영, 민병필 2004). 이에 따라 기업들은 판매촉진에 대한 투자를 확대하고 판매촉진 수단을 다양하게 활용하고 있어, 소비자들이 판매촉진 메시지의 폭탄세례 속에 살고 있다고 해도 과언이 아니다.

이러한 상황 속에서 기업은 판매촉진이 단기 적 성과에만 영향을 미친다는 부정적인 인식을 감소시키기 위한 대안의 필요성을 강조한다. 즉, 기업은 프로모션을 통해 소비자에게 가격가치의 상관관계를 변화시켜 즉각적인 판매를 일으키기 위한 단기적 판매 목표 뿐 아니라 브랜드 가치를 변화시킴으로써 장기적 커뮤니 케이션 목표를 달성시키고자 한다. 이와 같은 문 제를 해결하기 위해 기업들은 혁신적인 형태의 프로모션으로서 제휴 프로모션(tie-in promotion) 을 새로운 대안으로 도입하고 확산시키기 시작 하였다. 제휴 프로모션이란 이종 기업 간에 판 매 증가 및 이익률 향상 등과 같은 공동의 이 익을 위해 유사한 목표 고객을 대상으로 하여 촉진자원들을 공동으로 이용하는 등의 전략적
으로 묶인 형태로 정의할 수 있다. 최근 이동 통신사들은 여러 산업에 걸쳐 다양한 업체들과 제휴하여 마일리지 프로그램이나 할인혜택 등 의 프로모션 수단들을 활용한 공동 프로모션을 광범위하게 진행하거나, 대부분의 은행(카드), 호텔 및 리조트와 같은 서비스 기업들이 여러 업체들과 프로모션 제휴를 통하여 다양한 컨텐 츠의 문화행사 및 이벤트 등을 제공하는 것 등 을 실례로 들 수 있다.

제휴 프로모션에 대한 실무계의 활용이 커짐 에 따라 학계에서도 제휴 프로모션에 대한 관 심이 고조되고 있는데 제휴 프로모션에 대한 연구는 대체로 두 가지 형태로 분류될 수 있다. 첫째, 제휴 프로모션의 유형을 구분하기 위한 분류기준에 관한 연구(Varadarajan 1986; 2001, Kureshi and Vyas 2004; Farris and Quelch 1983)와 둘째, 제휴 프로모션에 참여한 파트너 기업의 선정요건과 제휴 프로모션 계획 시 고려해야하는 조건에 관한 연구(Varadarajan 1986; 2001, Kureshi and Vyas 2004)이다. 특히, 후자에 관한 연구들이 진행되어져 왔기 때문에 제휴 프로모션이 독특한 수단으로 활용 되어질 수(Kureshi and Vyas 2004) 있음에도 불구하고, 단지 전략적 제휴의 한 부분으로 간 주되어 기업적 관점에만 초점이 맞춰져 매우 제한적으로 연구되어졌다고 볼 수 있다. 이와 함께 제휴 프로모션의 구체적인 실증 연구 및 전략을 수립하기에 앞서 제휴 프로모션의 개념 을 명확하게 정의하고, 소비자 관점을 반영한 연구가 선행되어지지 않아 체계적인 연구가 매 우 부족한 실정이다.

따라서 본 연구의 목적은 다음과 같다. 첫째, 
현재 기업에서 실시하고 있는 제휴 프로모션 현황을 파악하고, 이에 따른 제휴 프로모션 수 단을 체계화시켜 그 개념을 명확히 정의하고자 한다. 둘째, 기존의 제휴 프로모션에 관한 연구 가 기업 중심적 관점에 초점을 맞추고 소비자 중심적 관점을 고려하지 않은 점에 착안하여, 제휴 프로모션에 대한 소비자의 인식을 질적연 구 자료분석 소프트웨어인 Nvivo 8을 사용하여 확인하고 범주화하고자 한다.

본 연구는 기존 연구에서 기업간 전략적 제 휴의 제한적 영역에서만 다루어졌던 제휴 프로 모션에 관한 연구를 소비자 관점으로 확대하여 그 연구의 범위를 확장함으로써 제휴 프로모션 의 유형을 구분하기 위한 향후 연구의 초석을 마련한다는 점에 이론적 시사점을 둔다. 이와 더불어 기업의 마케팅 관리자 및 판촉 관리자 에게는 판매촉진 효과를 극대화시키기 위해 적 합한 제휴 프로모션 수단을 찾아내는데 실무적 인 도움을 제공하게 될 것이다.

\section{II. 이론적 배경}

\section{1 전략적 제휴에 관한 연구}

전략적 제휴(strategic alliance)는 제휴 파트 너가 보유한 자산인 명성, 브랜드, 지식, 재무자 원, 기술 및 물리적 자원 등을 얻기 위하여 자 발적인 상호협력관계를 맺는 것으로 정의할 수 있다(Spekman et. al. 1998). 그리고 둘 이상 의 기업이 경쟁력 제고를 목표로 경영자원을 공유하거나 협업하기 위하여 일정기간 동안 지
속적 협력관계를 유지하는 것으로 정의되어져 왔다(홍유수 1994).

즉, 기업이 시장에서 열등한 위치에 있거나 많은 경쟁자들이 존재할 때 전략적 제휴가 체 결되어지며, 자신들이 가지고 있는 경쟁열위의 자원을 파트너기업의 경쟁우위의 자원으로 보 완함으로써 (1)자신이 속한 산업에서의 입지를 확고히 하고, (2)새로운 시장 진입을 용이하게 하며(Dacin \& Hitt 2000), (3)비용과 위험을 최소화시킴으로써 재무적인 자원을 얻을 수 있 다. 그러나 전략적 제휴는 높은 거래비용을 초 래(Williamson 1989; Hennart 1991)하거나, 발생된 이익이 제휴 기업들과 서로 공유하게 되어 수익의 흐름을 감소(Shan 1990)시키기 때 문에 긍정적인 효과만을 가지고 있는 것은 아 니다.

전략적 제휴의 유형에 관한 연구는 연구자나 연구관점에 따라 큰 차이를 보이고 있다. 일반 적으로 전략적 제휴 유형은 제휴의 동기, 상호 의존성, 기간, 범위, 내용, 계약 지분 유무 그리 고 협력 형태 등에 따라 수평-수직적 제휴 (Wildman 1998), X-Y형 제휴(Porter \& Fuller 1986) 그리고, 시장지향형-지술지향형 제휴(S. Das et al. 1998)로 구분된다. 수직적 제휴는 시장에서 지배력을 높이고 고객 및 시 장을 확보하기 위한 형태이며, 수평적 제휴는 기업의 가치사슬 상에 나타나는 약점을 보완하 고 규모의 경제를 실현하기 위한 방법으로 활 용된다. 한편 X형 제휴는 관련 기업이 서로 상 이한 분야에서 상대방을 보완하는 방식을 의미 하며, $\mathrm{Y}$ 형 제휴는 동일한 사업 분야에서 서로 협력하는 방식이다. 마지막으로 시장지향형 제 
휴라 함은 교차판매, 공동브랜드, 광고, 판촉, 채널, 판매를 통해 수요를 높이는데 그 목적이 있고, 기술지향형 제휴는 기술의 변화 속도가 빠르고 상품의 개발 과정이 복잡한 시장에서 요구되는 기술적 진보를 목적으로 한다.

전략적 제휴의 유형에 따른 성과는 크게 객 관적 성과와 주관적 성과로 구분하여 설명할 수 있다. 객관적 성과는 제휴를 통해 기업이 얻 게 되는 이익률, 성장성, 원가 절감과 같은 재 무적인 자료를 바탕으로 나타나는 성과를 의미 하며, 주관적 성과는 부실한 재무적 결과나 불 안정성에도 불구하고 실행된 전략적 제휴가 제 휴 형성의 전략적 목적이 충족되는 정도를 말 한다(Geringer \& Hebert 1991).

\section{2 제휴 프로모션에 관한 연구}

일반적으로 프로모션은 넓은 의미에서 광고, 인적판매, 퍼블리시티(publicity)와 기타 판매촉 진을 총칭하는 한편, 좁은 의미에서는 판매촉진 만을 의미한다. 이러한 프로모션의 정의에 따라 본 연구는 제휴 프로모션의 범위를 좁은 의미 의 프로모션 개념에 기반을 두고자 한다.

제휴 프로모션이란 이종 기업 간에 판매 증 가 및 이익률 향상 등과 같은 공동의 이익을 위해 유사한 목표 고객을 대상으로 하여 촉진 자원들을 공동으로 이용하면서 전략적으로 묶 인 형태를 의미하며, joint promotion, horizontal co-operative sales promotion, cross promotion 또는 umbrella sales promotion 등의 용어로 표현되고 있다(Kureshi 2004).
프로모션의 제휴와 관련된 연구로, Varadarajan(1986)은 협업적 판촉(cooperative sales promotion)의 분류기준으로, 기업 간/기 업 내 제휴, 동일/이종 제품군간 제휴, 단일/복 수 브랜드 간 제휴, 관련업계조합과의 연결 여 부, 자선모금과의 관련성 여부 등 5 개의 차원으 로 나누고 기업 간 이종상품군의 브랜드 간에 이뤄지는 공동판촉(joint sales promotion) 계 획 시 고려요소인 성장기회, 목표, 특징적인 편 익, 발생 가능한 문제 및 위험을 다루었다. 이 는 둘 또는 그 이상의 이종 기업들에 의해 제 조되어지는 브랜드간의 제휴로 같은 제품 카테 고리일수도 있고 다른 제품카테고리일수도 있 으며, 하나, 둘 또는 그 이상의 조직의 참여도 가능하다는 것을 의미한다(Vardarajan 1986).

마케팅적 관점에서의 제휴 프로모션은 기업 간에 이루어지는 전략적 제휴의 일환으로 극심 한 시장 경쟁상황에서 취약한 능력과 위험을 보완하여 경쟁력을 강화하고, 규모와 범위의 경 제를 실현하며, 목표시장으로 접근을 용이하게 하는 것에 그 의미를 둘 수 있다(Young, Gillbert and Mclntype 1996). 또한 Varadarajan(2001)은 협업적 판촉 관리를 위한 프레임웍을 제시하였다. 협업적 판촉 관리의 프 레임웍은 크게 분석 $\rightarrow$ 계획 $\rightarrow$ 실행 및 조정의 세 단계로 구성되어 있으며, 각 단계는 세부적 계 획에 따라 진행되어지는데 그 내용은 <표 1>과 같다. 이와 같은 단계는 반복적으로 일어나 제 휴 프로모션이 점점 체계화 되어져 현재 제휴 프로모션의 활용이 실무에서 매우 빈번하게 일 어나고 있다. 
이와 같은 제휴 프로모션의 효과는 다음과 같이 정리할 수 있다. 첫째, 두 기업이 협력적

〈표 1〉협업적 판매촉진의 관리를 위한 프레임웍

\begin{tabular}{|c|c|c|}
\hline I. 분석 & $\begin{array}{l}\text { 식별 } \\
\downarrow \\
\downarrow \\
\text { 정의 }\end{array}$ & $\begin{array}{l}\text { 협업적 판촉의 잠재적 기회 } \\
\text { 판매촉진 믹스의 넓은 영역 내 협업적 프로모션의 역할 }\end{array}$ \\
\hline ㅍ. 계획 & $\begin{array}{c}\text { 심사 } \\
\downarrow \\
\text { 개발 } \\
\downarrow \\
\text { 평가 } \\
\downarrow \\
\text { 탐색 } \\
\downarrow \\
\text { 사전테스트 } \\
\downarrow \\
\text { 정제 및 개발 } \\
\downarrow \\
\quad \text { 협상 } \\
\downarrow\end{array}$ & $\begin{array}{l}\text { 잠재적인 협업적 판촉 참여자 } \\
\text { 협업적 판촉 개념의 대안과 실험적 프로그램(인센티브의 규 } \\
\text { 모, 참여조건, 프로모션의 전달수단, 프로모션의 기간, 프로모 } \\
\text { 션의 시기, 임시적 예산수준)의 대안 } \\
\text { 협업적 판촉 프로그램의 대안과 비용-혜택분석을 통한 사전 } \\
\text { 준비 수행 } \\
\text { 잠재적 참여자 간의 프로모션 개념과 프로그램에 관한 관심 } \\
\text { 필수적인 경우, 프로모션 개념의 재검토 } \\
\text { 다른 잠재적 참여자들과 협의되어진 } \\
\text { 구체적 프로그램 } \\
\text { 제안된 프로그램의 참여 조건과 상황 } \\
\text { 참가조직의 관리에 의해 제안된 프로그램 }\end{array}$ \\
\hline III. 실행 및 조정 & $\begin{array}{c}\text { 실행 } \\
\downarrow \\
\text { 감독 } \\
\downarrow \\
\text { 수정 } \\
\downarrow \\
\text { 평가 }\end{array}$ & $\begin{array}{l}\text { 프로그램 } \\
\text { 프로그램의 진행과 수행 } \\
\text { 요구되는 경우, 중간단계에 실시 } \\
\text { 협업적 프로모션의 성과 }\end{array}$ \\
\hline
\end{tabular}

자료 : Varadarajan, P. R., "Joint Sales Promotion: An Emerging Marketing Tool," Business Horizons, Sept-Oct, 2001, pp.43-49. 
으로 계획을 촉진시킬 때, 공유되어진 비용으로 서 그들의 재정적 강점을 증가시킨다. 둘째, 인 력자원과 역량의 연합을 통해 더욱 효과적인 계획과 실행을 위한 혜택을 준다. 셋째, 제공된 인센티브의 높은 가치 때문에 중간상과 소비자 로부터 강화된 반응을 기대할 수 있다. 넷째, 규모가 작은 기업은 규모가 크고, 명성 있는 기 업(또는 브랜드)의 자산을 획득할 수 있다. 다 섯째, 관련되어 있지 않은 제품 또는 서비스는 공통의 목적을 성취하기 위해서 혁신적으로 촉 진되어질 수 있다. 즉, 서로 다른 기업들 사이 에서 그 결과로서의 공생적 관계는 소비자에게 추가적 가치를 제공함으로써 카테고리의 통합 을 촉진시킨다.

또한 제휴 프로모션의 효과가 기업에 미치는 영향으로 크게 세 가지를 들 수 있다. 첫째, 업 종별 또는 테마별 제품 및 서비스의 제휴효과 를 통해 신제품과 대체 상품의 판매를 위한 새 로운 표적시장 개발 및 신규 고객 창출이 용이 하다. 둘째, 일반적인 단일 기업의 경우, 프로모 션 예산이 적기 때문에 표적고객에게 자사를 인지시킬 수 있는 범위와 폭이 제한적인 한계 점을 가지고 있는데 제휴 프로모션을 활용하면 자사 브랜드의 고객 뿐 아니라 파트너 브랜드 의 고객에게까지 그 표적시장의 범위가 확대되 기 때문에 판촉효과를 극대화 시킬 수 있다. 셋 째, 유사업종 또는 이종업종 간의 제휴 프로모 션을 통해 제휴 당사자는 파트너 브랜드가 구 축한 명성으로 인한 브랜드 인지도나 이미지와 같은 브랜드 자산을 공유할 수 있을 뿐 아니라 소비자들에게 보여 질 수 있는 가능성이 높아 지기 때문에 그들의 반응을 즉각적으로 유도할
수 있다.

제휴 프로모션 유형에 관한 연구를 살펴보면, Farris and Quelch(1983)는 협업적 프로모션 을 내부적 수평적 제휴 프로모션(internal horizontal tie-in promotions), 외부적 수평적 제휴 프로모션(external horizontal tie-in promotions), 그리고 외부적 수직적 거래 프로 모션(external vertical trade promotions)으로 분류하기도 하였다. 또한 Kureshi and $\operatorname{Vyas}(2004)$ 의 연구에서는 협업적 판매촉진 (joint sales promotion)을 기업간/기업내 제휴 와 제품 카테고리(내구재, 비내구재, 서비스)에 따른 분류기준에 의해 구분하였다. 그들의 분석 결과에 따르면 제품 카테고리에 있어서는 내구 재와 내구재의 제휴가 $44.3 \%$ 로 가장 높은 비율 을 차지하고 있으며, 기업간/기업내에 있어서는 기업내 제휴 (18.6\%)에 비해 기업간 제휴 (81.4\%)가 압도적으로 나타나, 기업은 기업내 제휴의 유형보다는 기업간 제휴를 선호하는 것 으로 예상할 수 있다. 그들의 연구결과를 기반 으로 본 연구에서는 기업내 제휴 프로모션의 유형을 고려하지 않고 기업간 수평적 제휴 프 로모션의 유형에 한정하여 연구를 진행하고자 한다.

앞선 연구들과 같이 제휴 프로모션 유형에 관한 기존연구들은 기업간 전략적 제휴의 제한 적 영역에서만 다루어졌기 때문에 소비자 관점 으로 확대한 연구는 매우 미흡한 실정이다. 그 러므로 제휴 프로모션의 구체적인 실증 연구 및 전략을 수립하기에 앞서 제휴 프로모션 수 단의 개념을 명확하게 정의한 후, 제휴 프로모 션에 관한 소비자의 인식을 반영한 제휴 프로 
모션의 유형을 구분하기 위한 연구가 선행되어 야 할 필요성이 요구되어진다.

따라서 본 연구에서는 제휴 프로모션에 관한 사례분석을 통해 각 수단의 개념을 정의하고, 제휴 프로모션의 유형을 구분하기 위한 분류체 계를 모색하기 위하여 소비자 인식조사에 관한 질적 연구를 실시하였다.

\section{III. 연구방법 및 실증분석}

본 연구의 목적은 현재 기업에서 실시하고 있는 제휴 프로모션 현황을 파악하고, 이에 따 른 제휴 프로모션 수단을 체계화시켜 그 개념 을 명확히 정의하는데 있다. 또한 기존의 제휴 프로모션에 관한 연구가 기업 중심적 관점에 초점을 맞추고 소비자 중심적 관점을 고려하지 않은 점에 착안하여, 제휴 프로모션에 대한 소 비자의 인식을 확인하고 범주화하고자 한다. 이 를 위하여 본 연구를 두 단계로 구분하여, 연구 1 에서는 제휴 프로모션의 현황분석을 통해 제 휴 프로모션 수단의 체계화와 개념정의가 이루 어졌고, 연구 2 에서는 심층면접법을 이용하여 제휴 프로모션에 대한 소비자의 인식을 조사하 고, 질적연구 자료분석 소프트웨어인 Nvivo 8 을 사용하여 분석하였다.

\section{1 연구1: 제휴 프로모션 수단의 개념정의}

제휴 프로모션 수단의 개념을 정의하기 위해 세 단계로 구분하여 조사를 실시하였다. 첫 번 째 단계에서 2006년 1월부터 2010년 2월까지
의 제휴 프로모션 현황 및 사례에 관한 자료를 수집하였다. 인터넷 홈페이지에 나타난 프로모 션은 다양하고 정보 검색이 매우 용이하기 때 문에 실시간으로 7 개의 업종(자동차, 외식업, 패션 · 의류, 금융·카드·보험 서비스, 호텔, 식 품, 유통)으로 구분하여 실제 기업의 홈페이지 를 조사대상 사이트로 선정하였다. 각 업종에서 선택된 브랜드는 인터넷 검색어 순위에 따라 지명도가 가장 높은 순서를 따르고 있으며, 총 178건의 데이터를 수집하였다. 엑셀 프로그램 을 활용하여 업종별로 자사 브랜드명, 파트너 브랜드명, 그리고 구체적인 제휴 프로모션 내용 등으로 실제사례를 정리하였다.

두 번째 단계에서는 제휴 프로모션의 사례분 석을 통해 얻은 결과를 바탕으로 전문가 인터 뷰를 실시하였다. 인터뷰의 대상은 제휴 프로모 션을 직접 주최, 기획 및 실행하는 실무자들과 관련 학문 분야의 전문가들로서, 구체적으로 국 내 기업체의 프로모션 관련 실무자 3명, 마케팅 전공 교수 3 명, 마케팅 전공 박사과정 2명으로 이루어진 세 집단을 선정하였다. 각 집단에게 총 178 건의 제휴 프로모션 사례를 정리한 핸드 아웃을 제시한 후, 각 집단에서 자유로운 질문 과 토론을 거쳐 일반적인 판매촉진 수단(가격할 인, 쿠폰, 경품, 샘플, 보너스팩, 현금환불 등)을 바탕으로 제휴 프로모션의 수단을 명명하도록 요구하였다. 일반적인 판매촉진 수단으로 명명 할 수 없는 제휴 프로모션 수단에 대해서는 크 게 가격적 수단과 비가격적 수단으로 구분한 후, 적절히 표현할 수 있는 단어를 제시하도록 유도하였다.

마지막 단계에서 마케팅 전공 교수 1 명과 실 
무자 1 명을 선정하여 세 집단에 의해 유도된 제휴 프로모션 수단의 결과를 통합하고 재확인 하였다. 각 집단의 결과가 상이한 경우, 두 명 의 연구자가 해당 수단에 대해 합의를 거친 후 가장 적합한 제휴 프로모션 수단의 명명을 도 출해 내었다. 이를 통해 총 12 가지의 제휴 프 로모션 수단을 개발하고, 각 수단의 개념을 정 의하였다.

\subsection{1 제휴 프로모션 수단의 개념 정의}

본 연구에서는 사례분석을 통해 기업의 제휴 프로모션 현황을 파악한 후, 7 개의 업종에서 수 집된 174건의 제휴 프로모션 수단을 추출하였 다. 그 결과, 제휴 프로모션 수단은 제휴 가격 할인, 제휴 쿠폰, 제휴 회원제도, 제휴 콘테스 트, 제휴 경품, 제휴 프리미엄(유·무형), 제휴 샘플, 제휴 이벤트(문화이벤트, 자선이벤트, 체 험이벤트), 제휴 리펀드·리베이트로 나타났다. 본 연구에서는 제휴 프로모션 수단의 개념을 다음과 같이 정의하였다.

- 제휴 가격할인 : 제휴 가격할인은 당사자 기 업의 제품/서비스를 구매할 경우, 파트너 기 업의 제품/서비스를 할인 받을 수 있는 프로 모션 수단이다. 이는 자사제품 구매 시 파트 너사의 해당제품을 할인해 줌으로써 자사 제품의 즉각적인 구매를 유도함과 동시에 자사와 파트너사의 적정한 가격할인 비율을 통해 장기적인 관점에서 동종기업들과 극심 한 가격경쟁이 일어날 경우, 이윤의 감소와 브랜드 이미지 훼손을 예방할 수 있는 장점
을 가지고 있다.

- 제휴 쿠폰 : 제휴 쿠폰은 당사자 기업의 제 품/서비스를 구매할 경우, 파트너 기업의 제 품/서비스와 관련된 쿠폰을 제공하는 프로모 션 수단이다. 기존의 쿠폰은 소비자가 언제 쿠폰을 활용하였는지를 정확하게 추적할 수 없는 반면, 제휴 프로모션의 경우 파트너사 는 당사자 기업과 연계되어 발생하는 경비 를 공유해야 하므로 소비자의 제휴 쿠폰 사 용 시 그 시기를 정확히 예측할 수 있으며, 소비자의 반응 또한 어느 정도 확인할 수 있다.

- 제휴 회원제도 : 제휴 회원제도는 당사자 기 업의 제품/서비스를 구매할 경우, 자사의 마 일리지와 더불어 파트너 기업의 마일리지 및 포인트를 적립해주는 프로모션 수단이다. 자사의 고객에게 파트너사의 마일리지 및 포인트를 적립해 줌으로써 자사 고객의 프 로모션 사용 범위를 넓히고, 다양한 정보제 공의 혜택을 통해 고객확대 및 고정 고객화 를 하기 위해 사용되는 방법이다.

- 제휴 콘테스트 : 제휴 콘테스트는 당사자 기 업의 제품/서비스를 구매할 경우, 당사자 기 업과 파트너 기업이 공동으로 주최하는 콘 테스트에 참여할 수 있는 프로모션 수단이 다. 기존의 단독 콘테스트는 자사의 제품/서 비스에 관련된 것으로 콘테스트의 특성이 제한되어 있었으나, 제휴 프로모션의 경우 표적시장이 일치하는 이종 또는 동종의 기 업이 함께 진행하기 때문에 콘테스트의 특 성이 기존보다 확대된 것이라 할 수 있다.

- 제휴 경품 : 제휴 경품은 당사자 기업의 제 
품/서비스를 구매할 경우, 파트너 기업의 제 품/서비스와 관련된 경품을 제공하는 프로모 션 수단이다. 기존의 경품은 단지 우연에 의 해 추첨자가 결정되며 참여조건으로 구매를 증명할 필요가 없는 반면, 제휴 프로모션에 서의 경품은 자사의 구매 증명 또는 멤버쉽 의 여부가 밝혀져야 파트너사의 경품에 참 여할 수 있으므로 자사 고객만이 참여할 수 있다. 즉, 자사의 고객확대 및 고정 고객화 목적을 달성함에 있어 뛰어난 장점을 가지 고 있다.

- 제휴 프리미엄(유·무형): 제휴 프리미엄 (유-무형)은 당사자 기업의 제품/서비스를 구매할 경우, 파트너 기업의 제품/서비스와 관련된 유-무형의 사은품을 제공하는 프로 모션 수단이다. 기존의 프리미엄은 구매제품 과 연관된 유형의 제품만을 제공하였으나, 제휴 프리미엄은 어떤 유형의 파트너 기업 과 제휴를 하느냐에 따라 프리미엄 종류의 폭과 깊이가 다양화 될 수 있다.

- 제휴 샘플 : 제휴 샘플은 당사자 기업의 제 품/서비스를 구매할 경우, 파트너 기업의 제 품/서비스와 관련된 샘플을 제공하는 프로모 션 수단이다. 파트너사의 신상품 도입, 모델 변경 및 새로운 캠페인 행사시 제공되는 것 으로써 자사 고객에게 파트너사의 신제품에 대한 관심을 집중시키고, 인지도를 제고시킬 목적으로 사용된다.

- 제휴 지불조건 : 제휴 지불조건은 당사자 기 업의 제품/서비스를 구매할 경우, 자사에서 제공하는 지불조건과 더불어 파트너 기업이 제공하는 지불조건까지 사용할 수 있는 프
로모션 수단이다. 이는 신규 고객 확대 및 구매를 촉진시키기 위한 방법으로 자사 고 객이 제휴된 파트너사의 무이자 할부, 현금 가 분할 판매 및 제휴된 파트너사의 적립된 포인트-마일리지 사용 또는 제휴된 파트너 사가 발행한 상품권을 자사에서 이용할 수 있도록 지불조건을 다양하게 제공하는 것이 다.

- 제휴 이벤트 : 제휴 이벤트는 당사자 기업의 제품/서비스를 구매할 경우, 당사자 기업과 파트너 기업이 공동으로 다양한 이벤트를 제공하는 프로모션 수단이다. 이는 단기적 관점에서 소비자의 구매를 촉진시키는 것에 목적을 두기 보다는 장기적 관점에서 자사 의 브랜드 이미지를 강화시키기 위한 목적 으로 활용된다. 따라서 기존의 이벤트는 자 사의 브랜드 이미지를 강화시킴에 있어 한 계점을 가지고 있었으나, 제휴 이벤트는 파 트너사의 브랜드 이미지에 따른 후광효과에 의해 제휴 이벤트 효과를 극대화 시킬 수 있을 것으로 기대된다. 제휴 프로모션의 이 벤트는 다음과 같이 세 가지로 구분하여 설 명할 수 있다.

- 제휴 문화이벤트 : 자사와 파트너사가 공 동으로 재즈콘서트, 뮤지컬, 전시회 등과 같은 문화적 혜택을 제공하는 이벤트를 통 해 기존의 브랜드이미지에서 탈피하고, 새 로운 브랜드이미지를 구축시킬 수 있다.

- 제휴 체험이벤트 : 자사의 주요고객과 비 슷한 파트너사 고객의 눈앞에서 실제로 상 품을 보여주면서, 실연을 통해서 상품 사 용법을 설명하고 차별화된 우위성을 납득 
시킬 수 있다.

- 제휴 자선이벤트 : 자사와 파트너사의 제 휴 자선이벤트는 대의명분 마케팅(causerelated marketing)전략 차원에서 활용되 어 양자의 기업이미지를 향상시키고, 긍정 적인 브랜드 태도를 형성시킬 수 있다.

- 제휴 리펀드·리베이트 : 제휴 리펀드와 리 베이트는 당사자 기업의 제품/서비스를 구 매할 경우, 당사자 기업과 파트너 기업이 리 펀드 및 리베이트를 제공하는 프로모션 수 단이다. 파트너사의 기존 고객이었던 소비자 의 경우, 자사의 제품/서비스 구매가 처음이 라 할지라도 금전반환 혜택을 받을 수 있는 장점을 가지고 있다.

제휴 지불조건과 같은 제휴 프로모션 수단은 타 기업과의 협력이 이루어지지 않은 상태에서 단일 기업이 실행할 수 없기 때문에 일반 판매 촉진 수단에서는 존재하지 않는 형태라고 볼 수 있다. 제휴 지불조건을 제외한 제휴 프로모 션 수단들과 일반 판매촉진 수단을 비교해 보 았을 때, 표면상으로는 매우 유사한 특성을 가 지고 있는 것으로 보인다. 하지만 프로모션이 제공하는 혜택적 관점을 고려해본다면 제휴 프 로모션 수단은 일반 판매촉진 수단에 비해 신 뢰성을 기반 - 자기 기업(자사)과 파트너 기업 의 제휴를 통해 파트너 브랜드의 이미지 및 명 성의 전이에 의함 - 으로 하여 확장된 범위의 혜택을 제공한다는 측면에서 두드러진 차이를 보여준다.

[표 2]에서는 제휴 프로모션 수단의 개념정 의에 따라 현재 기업들이 실시하고 있는 제휴
프로모션의 대표적인 사례들이다. [표 2]를 살 펴보면, 제휴 브랜드 1 (자사 브랜드)과 제휴 브 랜드2(파트너 브랜드)가 함께 공동으로 진행하 고 있는 제휴 프로모션을 수단별로 구분하여 구체적인 사례내용을 함축하고 있다.

또한 업종에 따라 제휴 프로모션 수단별 건 수에 관한 결과를 살펴보면(〈표 3〉 참고), 금 융·카드·보험(93건), 외식업(34건), 호텔(23 건), 유통(20건), 식품(14), 의류(13), 자동차 (10) 순으로 나타나 전자의 네 서비스 업종이 나머지 세 비서비스 업종에 비해 제휴 프로모 션의 활용이 더욱 활발한 것으로 나타났다. 즉, 서비스 업종의 경우, 제품 및 서비스 자체에 대 한 차별성을 강조하기 어려움으로 인해 소비자 를 유인하기 위한 매력적인 프로모션이 요구되 어지므로 기업이 단독으로 진행하는 일반적인 프로모션 보다 둘 이상의 기업이 함께 참여하 여 확장된 혜택을 제공하는 제휴 프로모션 전 략이 더욱 효과적일 것으로 예상할 수 있다.

현재 기업들이 채택하고 있는 제휴 프로모션 수단들은 제휴 경품 24\%(50건), 제휴 가격할인 22\%(46건), 제휴 프리미엄 $16 \%$ (34건), 제휴 이벤트 8\%(18건), 제휴 콘테스트 $8 \%$ (17건), 제 휴 샘플 $6 \%$ (12건), 제휴 회원제도 5\%(10건), 제휴 지불조건 4\%(9건), 제휴 쿠폰 3\%(7건), 제휴 리펀드. 리베이트 $2 \%$ (5건)의 순으로 나 타나, 업종에 따른 차이는 있으나 평균적으로 대부분의 기업들은 타 기업과의 프로모션 제휴 에 있어 제휴 경품, 제휴 가격할인 및 제휴 프 리미엄 수단의 선호도가 높음을 예상할 수 있 다. 
[표 2] 기업들의 제휴 프로모션 사례

\begin{tabular}{|c|c|c|c|c|}
\hline \multicolumn{2}{|c|}{ 제휴 프로모션 도구 } & 제휴브랜드1 & 제휴브랜드2 & 제휴 프로모션 내용 \\
\hline \multirow{3}{*}{\multicolumn{2}{|c|}{ 제휴 가격할인 }} & 현대자동차 & 코오롱스포츠 & 현대차는 SUV 구매고객에게 코오롱 스포츠제품 구매 할인권 제공 \\
\hline & & KB카드 & G마켓 & $\mathrm{KB}$ 카드 여성고객을 위한 $\mathrm{G}$ 마켓 여성/유아용품 할인 이벤트 \\
\hline & & LIG손해보험 & 한진택배 & $\begin{array}{l}\text { LIG손해보험 고객이 쿠폰인증을 받아 한진택배 사이트를 방문하면 익일 } \\
\text { 택배 } 1,000 \text { 원을 할인 }\end{array}$ \\
\hline \multicolumn{2}{|c|}{ 제휴 쿠폰 } & $\mathrm{KB}$ 카드 & $\begin{array}{l}\text { 첼시프리미엄아 } \\
\text { 울렛 }\end{array}$ & $\begin{array}{l}\mathrm{KB} \text { 비자카드 고객에게 미국(40)과 일본(7) 내 첼시 프리미엄 아울렛 } \\
\mathrm{VIP} \text { 쿠폰복 또는 쿠폰시트 제공 }\end{array}$ \\
\hline \multirow{3}{*}{\multicolumn{2}{|c|}{$\begin{array}{l}\text { 제휴 회윈제도 } \\
\text { (마일리지·포인트 } \\
\text { 적립) }\end{array}$}} & 베니건스 & 마켓오 & 베니건스 결제금액의 $3 \%$ 를 마켓오 마일리지에 적립 \\
\hline & & 롯데호텔 & 제휴항공사 & $\begin{array}{l}\text { 롯데호텔에서 투숙시 제휴항공사 마일리지 회원에게 500마일의 마일리 } \\
\text { 지 적립 }\end{array}$ \\
\hline & & TGIF & SK텔레콤 & SK텔레콤 T멤버십 카드를 제시하면 TGIF에서 $10 \%$ 의 OK캐쉬백 적립 \\
\hline \multicolumn{2}{|c|}{ 제휴 콘테스트 } & 현대자동차 & 아가방 & $\begin{array}{l}\text { 출산의 행복과 기쁨이 담기 사진 중 우수작 } 50 \text { 개 선정 후 아가방 신생 } \\
\text { 아 용품 증정 }\end{array}$ \\
\hline \multicolumn{2}{|c|}{ 제휴 경품 } & 엔제리너스 & 기아자동차 & $\begin{array}{l}\text { 엔제리너스 커피를 이용하는 고객에게 추첨을 통해 기아자동차의 모닝 } \\
\text { 제공 }\end{array}$ \\
\hline \multirow{4}{*}{\multicolumn{2}{|c|}{$\begin{array}{l}\text { 제휴 } \\
\text { 프리미엄 } \\
\text { (유형· 무형) }\end{array}$}} & 동서식품 & 락앤락 & 동서식품의 맥심커피를 구입하면 락액락 쉐이커 증정 \\
\hline & & 신세계백화점 & 스타벅스 & 다량구매고객을 위한 상품권 패키지 구매시 스타벅스 관련 상품 증정 \\
\hline & & 신한카드 & 제휴스키장 & $\begin{array}{l}\text { 신한카드 제휴스키장에서 신한카드로 결제하면 최고 5천만원 스키보험 } \\
\text { 이 자동으로 무료가입 }\end{array}$ \\
\hline & & 삼성화재 & 제휴로펌 & $\begin{array}{l}\text { 애니홈 종합보험, 애니비즈 종합보험, 재물보험 애니홈, 뉴비지니스, } \\
\text { TOP운전자 보험에 가입하신 피보험자님께 삼성화재와 제휴를 맺은 국 } \\
\text { 내 로펌 변호사 및 회계사, 세무사 등이 관련내용을 무료로 상담 }\end{array}$ \\
\hline \multirow[t]{3}{*}{$\begin{array}{l}\text { 제휴 } \\
\text { 지불조건 }\end{array}$} & $\begin{array}{l}\text { 포인트 } \\
\text { 상품권 } \\
\text { 제휴 }\end{array}$ & 아웃백 & $\begin{array}{c}\text { 신세계백화점 } \\
\text { 갤러리아백화점 } \\
\text { AK백화점 } \\
\text { 롯데백화점 } \\
\text { SK } \\
\text { GS칼텍스 } \\
\text { 현대오일뱅크 } \\
\text { S-OIL } \\
\end{array}$ & 권을 아웃백에서 사용 가능 \\
\hline & & 빕스 & $\begin{array}{l}\text { 신세계 } \\
\text { 삼성카드 } \\
\text { 현대M카드 } \\
\text { 삼성카드 }\end{array}$ & 제휴 브랜드 포인트 결제 가능 \\
\hline & $\begin{array}{l}\text { 무이자 } \\
\text { 할부 }\end{array}$ & $\mathrm{KB}$ 카드 & 스피드메이트 & $\mathrm{KB}$ 카드 고객은 스피드메이트에서 행사기간동안 2-3개월 무이자 할부제공 \\
\hline \multicolumn{2}{|c|}{ 제휴 샘플 } & 엔제리너스 & 유한킴벌리 & $\begin{array}{l}\text { 엔제리너스커피를 이용하는 여성 고객을 위해 유한킴벌리의 여성용품 } \\
\text { 브랜드 애니데이와 함께하는 제휴 이벤트. 모든 여성 고객에게 애니데이 } \\
\text { '쁘띠윙' 샘플팩(2P, 선착순 } 10 \text { 만명)을 무료로 제공 }\end{array}$ \\
\hline \multirow{3}{*}{$\begin{array}{l}\text { 제휴 } \\
\text { 이벤트 }\end{array}$} & $\begin{array}{l}\text { 문화 } \\
\text { 이벤트 }\end{array}$ & 메리츠화재 & $\begin{array}{l}\text { 린덴바움 뮤직 } \\
\text { 페스티벌 }\end{array}$ & $\begin{array}{l}\text { 메리츠화재가 후원하는 린덴바움 뮤직 페스티발에 초대. 추첨을 통해 우 } \\
\text { 수고객 중 } 45 \text { 분께 초대권 } 2 \text { 매 제공 }\end{array}$ \\
\hline & $\begin{array}{l}\text { 자선 } \\
\text { 이벤트 }\end{array}$ & 나이키 & $R E D^{T M}$ & $\begin{array}{l}\text { 나이키는 아프리카의 에이즈 퇴치를 위해 노력하는 글로벌 펀드와 축구 } \\
\text { 프로그램에 판매이익을 전액기부 }\end{array}$ \\
\hline & $\begin{array}{l}\text { 체험 } \\
\text { 이벤트 }\end{array}$ & 커피빈 & $\begin{array}{l}\text { LG전자 } \\
\text { 폭스바겐 }\end{array}$ & $\begin{array}{l}\text { 서울 홍대앞, 신사동 가로수길, 청계천 등의 커피빈 매장서 커피를 마시 } \\
\text { 는 고객에게 뉴 비틀 차량 무료 시승 기회를 주고, 차량 내에서 '앤 } 37 \\
\text { 뉴 비틀 에디션'을 통해 음악을 들을 수 있게 한 것. 이외에도 여성 고 } \\
\text { 객들을 위해 남성 모델 } 2 \text { 명의 에스코트 서비스를 제공 }\end{array}$ \\
\hline \multicolumn{2}{|c|}{$\begin{array}{c}\text { 제휴 } \\
\text { 리펀드·리베이트 }\end{array}$} & 하나은행 & G마켓 & $\begin{array}{l}\text { 하나은행 통장(요구불 통장)으로 } \mathrm{G} \text { 마켓에서 쇼핑시 알뜰 쇼핑이체를 통 } \\
\text { 해 결제시 결제금액의 } 0.5 \% \text { 가 해당계좌로 바로 캐시백되는 서비스 }\end{array}$ \\
\hline
\end{tabular}


총 178 건의 제휴 프로모션 사례들이 178 개 의 수단이 아닌 208개의 제휴 프로모션 수단으 로 정리되어 있는데, 그 이유는 한 개의 제휴 프로모션 사례에서 하나 이상의 프로모션 수단 을 사용하고 있었기 때문이다.

\section{2 연구2 : 제휴 프로모션에 대한 소비자} 인식에 관한 질적 연구

\section{2 .1 질적 자료의 분석방법}

연구 2 에서는 앞서 연구1에서 제휴 프로모션 에 관한 사례분석을 통해 도출된 각 수단의 개 념을 정의 및 실례를 기반으로 제휴 프로모션 의 유형을 구분하기 위한 분류체계를 모색하기 위해서 소비자 인식조사에 관한 질적 연구를 실시하였다. 본 연구는 제휴 프로모션의 직접적 인 이용 및 간접적 이용(구전, 주변사람의 추천, 매체에 의한 접촉 등)에 의한 소비자의 인지
적 · 태도적 - 행동적 반응을 확인하고, 제휴 프 로모션에 대한 소비자 인식의 핵심범주를 추출 하고자 하였다.

본 연구는 제휴 프로모션에 대한 소비자의 인식을 알아보기 위하여 Strauss and Corbin (1998)의 근거이론(grounded theory) 방법론 을 사용하였다. 근거이론은 자료를 체계적으로 수집하고 지속적인 비교를 통하여 자료로부터 실체이론(substantive theory)을 생성하는 연구 방법론이다(나흥하 2008). 즉, 사실에 근거를 둔 자료들로부터 이론적 해석을 종합한 다음 새로운 이론을 구축하는데 그 목적이 있다.

본 연구에서 근거이론을 기반으로 자료분석 을 실시한 이유는 제휴 프로모션에 관한 연구 에 있어 소비자의 관점에 초점을 맞추어 소비 자들의 인지·의도 - 행동에 영향을 미칠 수 있 는 다양한 물리적, 심리적 변인에 대한 선행연 구가 이루어지지 않았기 때문이다. 근거이론은

[표 3] 업종에 따른 제휴 프로모션 수단별 건수

\begin{tabular}{|c|c|c|c|c|c|c|c|c|}
\hline 제휴 프로모션 수단 & 자동차 & 외식업 & 의류 & $\begin{array}{l}\text { 금융 } \\
\text { 카드 } \\
\text { 보험 }\end{array}$ & 호텔 & 식품 & 유통 & 계(\%) \\
\hline 제휴 가격할인 & 2 & 6 & & 35 & 3 & & & $46(22)$ \\
\hline 제휴 쿠폰 & - & 1 & - & 4 & 1 & - & 1 & 7(3) \\
\hline 제휴 회원제도 & - & 3 & 1 & 5 & 1 & - & - & 10(5) \\
\hline 제휴 콘테스트 & 1 & - & 4 & - & - & - & 12 & 17(8) \\
\hline 제휴 경품 & 3 & 13 & 6 & 12 & 1 & 9 & 6 & $50(24)$ \\
\hline 제휴 프리미엄 & 3 & 5 & - & 14 & 8 & 3 & 1 & $34(16)$ \\
\hline 제휴 지불조건 & - & 2 & - & 7 & - & - & - & $9(4)$ \\
\hline 제휴 샘플 & - & 2 & - & - & 9 & - & 1 & 12(6) \\
\hline 제휴 이벤트 & 1 & 2 & 2 & 11 & - & 2 & - & 18(8) \\
\hline $\begin{array}{c}\text { 제휴 } \\
\text { 리펀드· 리베이트 }\end{array}$ & - & - & - & 5 & - & - & - & $5(2)$ \\
\hline 계 & 10 & 34 & 13 & 93 & 23 & 14 & 20 & $208(100)$ \\
\hline
\end{tabular}


이와 같은 초기 연구의 부족함을 극복하고 개 념과 변인 발견을 통해 잠정적 이론화를 추구 하는데 유용하다(Strauss \& Corbin 1998). 뿐 만 아니라 근거이론은 제휴 프로모션에 대한 소비자의 심리적, 행동적 경험을 통해 형성될 수 있는 개념 및 범주를 도출할 수 있으며, 이 를 바탕으로 제휴 프로모션에 대한 소비자의 복잡한 인식을 구성하는 요소를 개발하여 새로 운 이론 정립을 시도할 수 있기 때문이다.

본 연구에서는 근거이론에 따라 질적연구의 진행순서로 첫째, 소비자 관점에서 제휴 프로모 션에 대한 인식을 탐색하고 상세화하며, 둘째, 질적 자료를 수집하고, 마지막으로 질적 자료 분석을 통해 결과를 밝히는 틀에 준하여 계획 되었다. 근거이론을 적용한 연구방법론의 연구 절차적 특징을 살펴보면, 근거이론에 의해 제기 된 제휴 프로모션에 관한 연구문제는 소비자 관점에서 연구될 특정 상황이나 어떤 조건하에 서 제휴 프로모션의 현상을 밝히는 진술과정을 통하여 소비자의 행동과 과정을 이끌어낼 수 있었다. 또한 제휴 프로모션과 소비자의 상호작 용을 이해하고 개념화하기 위하여 소비자 행위 의 실제적 영역으로부터 경험적 자료를 수집하 여 개념을 형성하고, 개발된 개념들의 수정 및 통합으로 실제적인 현상을 확인할 수 있었다. 마지막으로 본 연구는 근거이론의 연구절차 특 성에 따라 자료의 분석과정을 통해 제휴 프로 모션을 개념화 시킬 수 있는 새롭고 설명가능 성이 높은 개념들을 정립할 수 있었다.

본 연구는 질적 자료의 타당성과 신뢰도를 높이기 위하여 최근 6 개월 이내에 3 회 이상 제 휴 프로모션을 이용해 본 경험이 있는 10 명의
소비자를 대상으로 심층면접을 실시하였다. 심 층면접이 이루어지기 전 연구 1 의 제휴 프로모 션 사례분석 결과(제휴 프로모션 현황, 제휴 프 로모션 수단의 개념 정의 및 사례, 업종별 제휴 프로모션 선호 현황)를 스크랩하여 보여주고, 자신의 구체적인 경험을 상기하도록 유도하였 다.

진행된 심층면접에서 진행자(moderator)의 사회로 인터뷰의 취지를 소개하고, 연구주제에 대한 이해가 충분히 이루어진 후에 서술적인 개방형 질문에서 시작하여 구체적인 경험을 이 끌어낼 수 있도록 세부 질문으로 좁혀 들어가 도록 했다. 또한 이에 대한 각자의 의견을 자유 롭게 이야기 하도록 하였으며, 인터뷰 진행 중 참여자들의 이야기를 통해 드러나는 사건이나 사실들에 대한 질문이 요구되는 경우, 추가질문 에 대한 대답을 유도해나가는 방식을 취하였다. 인터뷰 시간은 대화의 집중력 확보를 위하여 1 인당 1 시간으로 정하였으나, 특정 대상자의 경 우 최대 3시간이 소요되기도 하였다. 심층면접 시 기록요원 1 명을 고정으로 배치해 전문가들 이 사회자의 질문에 답하는 내용을 요약하도록 하였으며, 인터뷰가 진행되는 동안 녹음기를 통 해 모든 인터뷰 내용을 녹취하였으며, 녹음된 내용은 인터뷰가 끝난 즉시 텍스트로 변환하여 저장하였다.

\subsubsection{Nvivo 8을 이용한 자료처리 및 분석 결과}

본 연구에서는 대중성과 이용의 용이성을 고 려하여 여러 질적자료 분석 소프트웨어 중 Nvivo 8을 선택하였다. Nvivo 8은 질적 연구 
를 위한 소프트웨어 중 가장 대중적인 QSR NUD*IST(non-numetric unstructured data indexing, searching and theorizing)의 최신 버전으로서, 텍스트에 드러난 정보를 노드(nod) 를 만들어 핵심 주제들로 구조화할 수 있기 때 문에 보고자 하는 대상의 의미를 구조화시켜 드러내는데 유용하다(박종원 2009). 또한 이 소 프트웨어를 이용할 때 취할 수 있는 장점은 질 적인 연구 자료에서 정보를 가공하고, 그 결과 를 양적인 수치로 확인할 수 있다는 점이다. 즉 코딩 빈도와 백분율은 물론, 전체 자료의 양에 서 해당 코딩 부분의 커버리지 등이 정확하게 수치로 파악된다(김은성 2007).

본 연구에서 취한 처리 방식을 간략하게 설 명하면 다음과 같다. 먼저, 조상대상자에 의한 인터뷰 자료를 Nvivo 8에 적합한 파일 형식으 로 바꾸어 저장한 후 이를 불러들여 제휴 프로 모션에 대한 인식에 해당하는 부분들을 선택하 여 일차적으로 노드(nod)를 만들었다.

1 단계 노딩 작업에서는 총 157 개의 노드를 만들었으나 이것들을 검토하여 잘못 처리한 부 분과 의미가 동일하거나 세분되는 것 등을 수 정 과정을 통해 최종적으로 총 142 개의 노드만 이 사용되었다. 이 잠정적인 중간 결과물을 다 시 재검토하여 위계적으로 구조화한 2단계 노
딩 작업을 실시하였다. 즉, 본 연구에서는 처음 부터 제휴 프로모션의 인식과 관련된 요인들을 구조적으로 범주화하고, 위계적으로 분석하지 않고 귀납적 방식으로 접근하기 위해 조사대상 자의 인터뷰 자료에서 시작하여 범주를 생성하 고 수정하면서 점차 체계적인 구조를 갖춘 개 방적 코딩 방식을 선정하였다.

자료를 분석한 결과, 〈표 4>에 나타난 바와 같이 제휴 프로모션에 대한 소비자의 인식은 크게 '선호하는 제휴 프로모션의 특성', '제휴 프로모션의 기대혜택', '제휴 프로모션의 위험요 소' 측면의 총 세 가지 주요 범주로 설명될 수 있다. 이상의 세 가지 범주에서 보여주고 있듯 이 제휴 프로모션에 대한 소비자들의 인식은 선호하는 제휴 프로모션의 특성과 기대혜택과 같은 긍정적인 평가요인과 제휴 프로모션의 위 험요소와 같은 부정적인 평가요인이 함께 작용 할 수 있다는 것이다.

\subsubsection{1 선호하는 제휴 프로모션의 특성}

소비자들은 선호하는 제휴 프로모션의 특성 으로 특별한 경험, 제휴 프로모션의 편리성, 제 휴 프로모션의 희소성, 금전적 가치 등이 있는 것으로 나타났다. 특히, 제휴 프로모션의 특별 한 경험 제공(21) 요인은 제휴 프로모션을 통해

〈표 4〉자료 분석 결과 도출된 주요 범주

\begin{tabular}{|c|l|c|c|}
\hline \multicolumn{2}{|c|}{ 주요범주 } & 코딩수 & 빈도(\%) \\
\hline I & 선호하는 제휴 프로모션의 특성 & 80 & 56 \\
\hline II & 제휴 프로모션의 기대혜택 & 44 & 31 \\
\hline III & 제휴 프로모션의 위험요소 & 18 & 13 \\
\hline
\end{tabular}


다양한 경험과 새로운 경험을 할 수 있다는 내 용으로 구분할 수 있으며, 금전적 가치 제공 (15) 요인은 제휴 프로모션의 경우 다양한 가격 할인을 제공해주고, 그 활용범위가 넓다는 내용 으로 구분할 수 있다. 즉, 제휴 프로모션의 금 전적 가치는 일반적 판매촉진 수단인 가격할인 의 판촉유형이 단지 특정 구매제품의 가격만을 할인해주는 것에 비해 할인 제품의 범위가 확 대되고, 다양한 형태의 가격할인이 제공되는 점 에서 보다 확장된 의미의 금전적 가지를 가지 고 있다(〈표 5〉 참고).

이상의 내용을 정리하면 핵심범주 I 은 크게 금전적 가치와 비금전적 가치(특별한 경험제공, 제휴 프로모션의 편리성, 제휴 프로모션의 희소 성)로 구분된다. 한 기업이 판매촉진전략을 실 행하는 경우, 판촉수단의 유형에 따라 금전적 가치의 효율성이 높거나 비금적인 가치의 효율 성이 높은 것으로 나타난다. 반면 제휴 프로모 션은 자사 기업과 파트너 기업이 공동으로 프 로모션 전략을 실행하기 때문에 각각의 제휴 프로모션 수단은 소비자들에게 금전적 가치와 더불어 비금전적 가치를 제공한다. 예를 들어,
제휴 리펀드 및 리베이트(예: 하나은행 통장으 로 $\mathrm{G}$ 마켓에서 쇼핑시 알뜰 쇼핑이체를 통해 결 제시 결제금액의 $0.5 \%$ 가 해당계좌로 바로 캐시 백되는 서비스)를 받게 되면, 소비자는 다시 돌 려받은 현금을 보면서 금전적 가치가 극대화됨 과 동시에 다른 은행 또는 온라인 쇼핑몰에서 받을 수 없었던 서비스의 희소성을 인지함으로 써 비금전적 가치까지 증가하게 되는 현상을 경험하게 되는 것이다.

\subsubsection{2 제휴 프로모션의 기대혜택}

소비자들은 제휴 프로모션의 기대혜택으로 제휴 프로모션과 자아추구혜택과의 적합성, 구 매제품과 프로모션 간의 보완성, 유명한 파트너 브랜드와 제휴, 다양한 프로모션 제공, 구매 제 품과의 관련성, 구매제품과 제휴 프로모션의 컨 셉 일치 등을 언급하였다. 특히, 제휴 프로모션 과 자아추구혜택과의 적합성의 하위범주에 속 하는 세부항목들을 살펴보면 개인이 추구하는 목적과 일치성, 개인적으로 빈번히 사용하는 제 품 또는 서비스와의 제휴 및 제품에 따라 개인 의 취향과의 일치성이 나타났다.

\section{〈표 5〉범주 | 의 분석결과}

\begin{tabular}{|c|c|}
\hline \multirow{4}{*}{$\begin{array}{l}\text { 제휴 프로모션을 } \\
\text { 선호하는 이유 }\end{array}$} & $\begin{array}{l}\text { 특별한 경험 제공 }(21) \\
\text {-다양한 경험 제공 } \\
\text {-새로운 경험 제공 }\end{array}$ \\
\hline & 제휴 프로모션의 편리성(6) \\
\hline & 제휴 프로모션의 희소성(2) \\
\hline & $\begin{array}{l}\text { 금전적 가치 제공(15) } \\
\text {-다양한 가격할인의 제공 } \\
\text {-활용범위가 넓은 가격할인의 제공 }\end{array}$ \\
\hline
\end{tabular}


전체 코딩수(80)의 약 $55 \%$ 를 차지하는 것은 제휴 프로모션과 자아추구혜택과의 적합성(44) 으로 나타났는데, 이는 제휴 프로모션의 강력한 특성요인으로 간주된다(〈표 6> 참고). 이러한 연구결과는 제휴 프로모션에 관한 기존연구에 서 기업간 프로모션의 제휴가 이루어짐에 있어 파트너의 선정이 매우 중요한 요인으로 제기되 었듯이, 소비자에게도 파트너와 관련된 요소는 제휴 프로모션 선호 요인과 매우 밀접한 관련 이 있는 것으로 예상할 수 있다. 그러나 소비자 가 파트너를 평가하는 경우, 파트너가 보유한 명성, 브랜드, 지식, 재무자원, 기술 및 물리적 자원과 같은 요인보다는 소비자가 제휴 파트너 의 관계를 기반으로 혜택을 극대화 시키고자 하는 요인에 그 구심점을 두고 있다. 즉, 제휴
프로모션에 대해 소비자자 기대하는 혜택은 기 업이 전략적 제휴를 통해 획득 할 수 있는 혜 택과는 차이가 있음을 예상할 수 있다.

\subsubsection{3 제휴 프로모션의 위험요소}

소비자들은 제휴 프로모션의 위험요소로 개 인정보 유출, 제휴 기업에 대한 불신, 회원가입 시 동의 없이 자동 갱신, 자격요건의 제한, 제 휴 프로모션의 사용 이후 재구매 강요, 제휴 프 로모션에 대한 추가 비용의 지불 등이 언급되 었다. 이 중에서 소비자들은 동의서 작성, 신청 서 작성, 회원가입의 경우 노출되는 개인정보에 의해 지각된 위험이 매우 높음을 알 수 있다 (〈표 7〉 참고).

이상의 결과는 일반적인 판촉활동을 통해서

\section{〈표 6〉범주 || 의 분석결과}

\begin{tabular}{|c|l|}
\hline \multirow{5}{*}{$\begin{array}{c}\text { 제휴 프로모션의 } \\
\text { 기대혜택 }\end{array}$} & $\begin{array}{l}\text { 제휴 프로모션과 자아추구혜택과의 적합성(44) } \\
\text { - 개인이 추구하는 목적과 일치 } \\
\text {-개인적으로 빈번히 사용하는 제품 또는 서비스와의 제휴 } \\
\text {-제품에 따라 개인의 취향과 일치하는 것 }\end{array}$ \\
\cline { 2 - 3 } & 구매제품과 프로모션 간의 보완성(12) \\
\cline { 2 - 3 } & 유명한 파트너 브랜드와 제휴(10) \\
\cline { 2 - 3 } & 다양한 프로모션 제공(4) \\
\cline { 2 - 3 } & 구매 제품과의 관련성(6) \\
\cline { 2 - 3 } & 구매제품과 제휴 프로모션의 컨셉 일치(4) \\
\hline
\end{tabular}

\section{[표 7] 범주 || $\mid$ 의 분석결과}

\begin{tabular}{|c|l|}
\hline \multirow{4}{*}{\begin{tabular}{c}
$*$ \\
\multirow{4}{*}{ 제휘험요소 }
\end{tabular}} & 개인정보 유출(6) \\
\cline { 2 - 3 } & 제휴 기업에 대한 불신(2) \\
\cline { 2 - 3 } & 동의 없이 자동 갱신(2) \\
\cline { 2 - 3 } & 이용시 부담감(2) \\
\cline { 2 - 3 } & 자격요건의 제한(2) \\
\cline { 2 - 3 } & 제휴 프로모션의 사용 이후 재구매 강요(2) \\
\cline { 2 - 3 } & 제휴 프로모션에 대한 추가 비용의 지불(2) \\
\hline
\end{tabular}


도 발견될 수 있다. 그러나 단일 기업이 판촉을 실시하는 경우에 비해서 둘 이상의 기업이 프 로모션 전략에 공동으로 참여하였을 때 소비자 가 지각하게 되는 위험요소는 증가하게 된다. 왜냐하면 제휴 프로모션 전략을 통해 자사 기 업 및 파트너 기업이 공동의 목표에 도달하기 위해서 소비자의 정보를 많이 가지고자 하는 의도가 강하게 나타나기 때문이다. 그러므로 제 휴 프로모션의 사용으로 인해 소비자가 자사 및 파트너 기업에 노출되면 될수록 소비자들은 개인정보의 제공을 요구받게 되고, 그에 따른 지각된 위험이 증가하게 되는 것이다. 따라서 제휴 프로모션 전략을 수행하는 과정에 있어 소비자들이 인지할 수 있는 위험요소들을 제거 함으로써 소비자들의 지각된 위험 수준을 낮추 려는 노력이 필요하다.

\section{$\mathrm{I}$. 결론 및 시사점}

제휴 프로그램이 혁신적인 형태의 프로모션 이자 새로운 대안으로 시장내에 활발히 도입 및 확산됨으로써 이에 대한 관심이 증가하고 있음에도 불구하고, 제휴 프로모션에 관한 학문 적 연구가 미흡한 실정이다. 이에 따라 본 연구 의 목적은 제휴 프로모션 수단을 체계화시켜 개념을 정의하고, 제휴 프로모션에 대한 소비자 의 인식을 확인하는 데 있다. 본 연구는 기존 연구에서 기업간 전략적 제휴의 제한적 영역에 서만 다루어졌던 제휴 프로모션에 관한 연구를 소비자 관점으로 확대하여 그 연구의 범위를 확장함으로써 제휴 프로모션의 유형을 구분하
기 위한 향후 연구의 초석을 마련한다는 점에 이론적 시사점을 두고 진행하였다. 이를 통해 실무적으로 판매촉진 효과를 극대화시키기 위 해 적합한 제휴 프로모션 수단을 찾아내는데 실질적인 도움을 제시하고자 한다.

이러한 연구목적을 위해, 본 연구는 현재 업 계에서 진행하고 있는 다양한 형태의 제휴 프 로모션 현황을 파악하고, 제휴 프로모션에 대한 소비자의 인식을 조사하기 위해 심층면접을 실 시하였다. 제휴 프로모션의 사례분석과 심층면 접을 실시한 결과는 다음과 같이 요약할 수 있 다.

첫째, 사례분석을 통해 제휴 프로모션 수단을 제휴 가격할인, 제휴 쿠폰, 제휴 회원제도, 제휴 콘테스트, 제휴 경품, 제휴 프리미엄(유·무형), 제휴 지불조건, 제휴 샘플, 제휴 이벤트(문화이 벤트, 자선이벤트, 체험이벤트), 제휴 리펀드. 리베이트로 체계화시켜 각 수단에 대한 개념을 정의하였다. 이중에서 제휴 지불조건과 같은 제 휴 프로모션 수단은 타 기업과의 협력이 이루 어지지 않은 상태에서 단일 기업이 도입할 수 없으므로 일반 판매촉진 수단에서는 존재하지 않는 형태라고 볼 수 있다. 제휴 지불조건을 제 외한 나머지 제휴 프로모션 수단들은 일반 판 매촉진 수단과 비교하여 표면상으로는 매우 유 사한 특성을 가지고 있는 것으로 나타났으나, 제휴 프로모션 수단은 일반 판매촉진 수단에 비해 신뢰성을 기반으로 하여 확장된 범위의 혜택을 제공한다는 측면에서 두드러진 차이를 보여준다.

둘째, 심층면접법을 이용하여 제휴 프로모션 에 대한 소비자의 인식에 관한 자료를 수집하 
여 분석을 실시하였다. 분석을 위해 질적 자료 의 체계적 처리 및 분석 방법적인 측면을 고려 하는 질적 연구를 위한 소프트웨어인 Nvivo 8 을 이용하였다. 분석결과, 제휴 프로모션에 대 한 소비자의 인식은 크게 '선호하는 제휴 프로 모션의 특성', '제휴 프로모션의 기대혜택', '제 휴 프로모션의 위험요소' 측면의 총 세 가지 주 요 범주로 설명될 수 있다. 선호하는 제휴 프로 모션의 특성으로는 특별한 경험, 제휴 프로모션 의 편리성, 제휴 프로모션의 희소성, 금전적 혜 택 등이 있다. 특별한 경험이란 제휴 프로모션 을 통한 다양한 경험과 새로운 경험을 포함하 고 있다. 이상의 내용에서 확인할 수 있듯이 소 비자들은 제휴 프로모션의 지각된 가치로 금전 적인 가치와 더불어 비금전적인 가치를 인지하 는 것으로 예상할 수 있으며, 비교적 금전적 혜 택보다는 비금전적 혜택에 가중치를 두어 평가 하는 경향을 보이고 있음을 확인하였다. 즉, 한 기업이 판매촉진전략을 실행하는 경우, 판촉수 단의 유형에 따라 금전적 가치의 효율성이 높 거나 비금적인 가치의 효율성이 높은 것으로 나타난 반면, 제휴 프로모션은 자사 기업과 파 트너 기업이 공동으로 프로모션 전략을 실행하 기 때문에 각각의 제휴 프로모션 수단은 소비 자들에게 금전적 가치와 더불어 비금전적 가치 를 제공하는 것이다.

이와 같이 제휴 프로모션은 소비자에게 복합 적 가치를 제공해 줌으로써 소비자의 구매의사 결정과정에 긍정적인 영향을 미치는 마케팅커 뮤니케이션 프로그램이며, 두 기업의 차별적 우 위를 활용하여 때로는 금전적인 특성을 강조시 키거나 비금전적인 특성을 강조시켜 소비자에
게 유연한 제휴 프로모션을 제공할 수 있을 것 이다. 이는 단기적 목표뿐만 아니라 중장기적 목표를 달성시키는 마케팅 전략으로 폭넓게 활 용될 수 있다.

제휴 프로모션의 기대혜택으로는 제휴 프로 모션과 자아추구혜택과의 적합성, 구매제품과 프로모션 간의 보완성, 유명한 파트너 브랜드와 제휴, 다양한 프로모션 제공, 구매 제품과의 관 련성, 구매제품과 제휴 프로모션의 컨셉 일치 등이 있다. 그 중에서도 제휴 프로모션과 자아 추구혜택과의 적합성이 차지하는 비율이 가장 높은 것으로 나타났는데, 제휴 프로모션의 특성 요인으로서 제휴 프로모션과 자아추구혜택과의 적합성은 매우 흥미로운 결과로 보여진다. 즉, 자기추구혜택과 일치하는 제휴 프로모션은 소 비자의 브랜드의 구매를 촉진시키는 반면, 자기 추구혜택과 일치하지 않는 제휴 프로모션은 소 비자에게 외면당하기 쉽다. 다시 말하면 제휴 프로모션이 높은 수준의 쾌락적 혜택을 제공하 는 경우, 소비자는 그러한 쾌락적 혜택이 자신 의 자기추구혜택과 일치할 때에는 긍정적인 반 응을 보이지만, 그렇지 않을 경우에는 부정적인 반응을 나타낼 수 있다는 것이다. 따라서 제휴 프로모션은 일반 판매촉진에 비해 소비자들에 게 제공된 제휴 프로모션과 자신이 추구하는 혜택의 적합성이 높을수록 선호된다는 것이다. 따라서 이러한 결과는 소비자 관점을 고려하여 제휴 프로모션 전략을 수립함에 있어 그 중요 성이 강조되어야 할 것이다.

제휴 프로모션의 위험요소로는 개인정보 유 출, 제휴 기업에 대한 불신, 회원가입의 경우 동의 없이 자동 갱신, 자격요건의 제한, 제휴 
프로모션의 사용 이후 재구매 강요, 제휴 프로 모션에 대한 추가 비용의 지불 등이 있다. 이 중에서 소비자의 지각된 위험이 가장 큰 요소 는 개인정보의 유출이었다. 즉, 둘 이상의 기업 이 프로모션 전략에 공동으로 참여하였을 때 소비자가 지각하게 되는 위험요소는 증가하게 되는데, 이는 제휴 프로모션 전략을 통해 자사 기업 및 파트너 기업이 공동의 목표에 도달하 기 위해서 소비자의 정보를 많이 가지고자 하 는 경향이 강하게 나타나기 때문이다. 일단 소 비자에게 부정적 태도가 형성되면 소비자의 태 도를 긍정적으로 변화시키기 위해 기업의 수많 은 노력이 요구되므로 제휴 프로모션 전략을 수행하는 과정에 있어 지각될 수 있는 위험 요 소를 제거하거나 위험수준 정도를 낮추려는 시 도의 필요성이 강조되어야 한다.

본 연구는 기존의 제휴 프로모션에 관한 연 구를 확장하여 제휴 프로모션 수단의 개념을 정의하고 제휴 프로모션에 대한 소비자의 인식 을 조사하였음에도 불구하고, 다음과 같은 한계 점과 향후 연구방향을 설정할 수 있다.

첫째, 본 연구에서는 기업 간 수평적 제휴 프 로모션의 유형만을 취급하였으나, 추후의 연구 에서는 다양한 전략적 제휴 프로모션의 상황을 고려하여 나타날 수 있는 제휴 프로모션 수단 을 다각적으로 고려할 필요가 있다.

둘째, 제휴 프로모션의 사례를 분석을 통해 각 수단의 개념을 정의하였음에도 불구하고, 체 계적으로 각각의 제휴 프로모션 수단에 대한 소비자 인식에 관한 탐색적 연구가 이루어지지 못하고, 전반적인 제휴 프로모션에 관한 질적 연구에 그쳤다. 향후 제휴 프로모션의 유형구분
을 위한 연구에서는 이러한 요인을 세부적으로 다루어 제휴 프로모션 수단 자체에 초점을 맞 추어 진행할 필요성이 제기된다.

셋째, 제휴 프로모션에 대한 소비자의 인식을 조사하기 위한 연구 대상을 한계점으로 들 수 있다. 본 연구에서는 최근 6 개월 이내에 3 회 이상의 제휴 프로모션을 이용한 경험이 있는 소비자만을 대상으로 조사를 실시하여 그들이 가지고 있는 제휴 프로모션에 대한 인식의 공 통성이 높았다. 따라서 다양한 소비자 인식을 조사하기 위해서는 연구대상의 개인적 특성을 반영할 수 있는 연구 방법을 설계하여 일반화 의 가능성을 보다 제고시켜야 할 것이다.

<논문 접수일: 2010. 08. 24> <게재 확정일: 2011. 04. 08>

\section{참고문헌}

김은성(2007), "학습자들은 왜 문법학습을 꺼리 는가?: 문법학습 부진 요인에 대한 연구,' 국어교육학회, 40, 35-72.

김주영, 민병필(2004), “판매촉진 수단 유형의 판촉효과 비교," 경영학연구, 34(2), 445-469.

나흥하(2008), “초등학교 교사가 일제시험 기간 에 겪는 경험의 실체," 초등교육연구, 21(3), 405-435.

박종원(2009), 현장연구자를 위한 질적데이터의 과학적 관리와 분석 : Nvivo 8 프로그램의 활용, 형설출판사.

하동현, 김시현(2009), “패밀리 레스토랑에서의 
판매촉진에 의거한 세분시장에 관한 연구 : 전략적 제휴 혜택의 판매촉진을 중심으로," 한국식품조리과학회지, 25(5), 531-544.

홍유수(1994), "전략적 제휴와 기술혁신의 국제 화”, KIEP연구보고서(대외경제정책연구원).

Bawa, K. and Robert W. Shoemaker(1987), "The Coupon-Prone Consumer Some Findings Based on Purchase Behavior across Product Classes," Journal of Marketing, 51, 99-110.

Blattberg, Robert, Gary D. Eppen, and J. Lieberman(1981), "A Theoretical and Empirical Evaluation of Price Deals for Consumer Nondurables," Journal of Marketing, 45(Winter), 116-129.

Cotton, B. C. and Emerson M. Babb(1978), "Consumer Response to Promotional Deals," Journal of Marketing, 42(July), 109-113.

Dacin, M. A. and M. T. Hitt(2000), "Partner Selection in Emerging and Developed Market Contexts: Resource-Based and Organizational Learning Perspectives," Academy of Management Journal, 43(3), 449-467.

Das, S., P. K. Sen, and S. Sengupta(1998), "Impact of Strategic Alliances on Firm Valuation," Academy of Management Journal, 41(1), 27-41.

Dodson, Joe, Alice Tybout, and Brian Sternthal(1978), "Impacts of Deals and Deal Retraction on Brand Switching,"
Journal of Marketing Research, 15, 72-81.

Farris, P. W. and J. A. Quelch(1983), "Advertising and Promotion Management: A Manager's Guide to Theory and Practice," Radner, PA: Chilton.

Geringer, J. M. and L. Hebert(1991), "Measuring Performance of International Joint Ventures," Journal of International Business Studies, 22(2), 249-264.

Guadagni, Peter M. and John D. C. Little(1983), "A Logit Model of Brand Choice Calibrated on Scanner Data," Marketing Science, 3(Summer), 203-238. Henderson, Caroline M.(1985), "Modeling the Coupon Redemption Decision," Advances in Consumer Research, 12, 138-143.

Hennart, J. F.(1991), "The Transaction Costs Theory of Joint Ventures: An Empirical Study of Japanese Subsidiaries in the United States," Management Science, 37(4), 483-497.

Jeuland, Abel P. and Chakravarti Narasimhan(1985), "Dealing-Temporary Price Cuts by Seller as an Buyer Discrimination Mechanism," Journal of Business, 58(July), 295-308.

Kotler, P.(1997), Marketing Management: Analysis, Planning and Control, 9th ed, 
Prentice-Hall Inc.

Kuehn, Alfred A., and A. C. Rohloff(1967), Evaluating Promotion Using a Brand Switching Model, in Promotional Decisions Using Mathmatical Models, ed. P. Robinson, 50-85.

Kureshi, Sonal and Preeta Vyas(2004),

"Joint Sales Promotion : Prospects and Issues," IIMB Management Review, Sept, 25-30.

Narasimhan, Chakravarti(1984), “A Price

Discrimination Theory of Coupon," Marketing Science, 3(spring), 128-147.

Neslin, Scott A. and Robert W. Shoemaker(1983), "A Model for Evaluating the Profitability of Coupon Promotion," Marketing Science, 2(Fall), 361-388.

Neslin, Scott A., Caroline Henderson, and John Quelch(1985), "Consumer

Promotion and the Acceleration of Product Purchases," Marketing Science, 4(Spring), 147-165.

Massy, William F. and Ronald E. Frank(1965), "Short Term Price and Dealing Effect in Selected Marketing Segments," Journal of Marketing Research, 2(May).

Montgomery, David B.(1971), “Consumer Characteristics Associated with Dealing : An Empirical Example," Journal of Marketing Research, 8(May), 118-120.
Porter, M. E. and M. B. Fuller(1986), Coalitions and Global Strategy, Competition in Global Industries, Harvard Business School Press.

Rossiter, J. R. and L. Percy(1987), Advertising and Promotion Management, McGraw-Hill, New York, NY, USA., 24-36.

Rothchild M. L. and W. C. Gaidis(1981). "Behavioral Learning Theory: Its Relevance to Marketing and Promotion," Journal of Marketing, 45(Spring), 70-78.

Sawyer, A. G. and P. R. Dickson(1984), Psychological Perspectives on Consumer Response to Sales Promotion in Research on Sales Promotion: Collected papers, Katherine E Josz, ed. Cambridge MA: Marketing Science Institute, 47-62.

Shan, W.(1990), "An Empirical Analysis of Organizational Strategies by Entrepreneurial High-Technology Firms," Strategic Management Journal, 11(2), 129-139.

Spekman, R. E., T. M. Forbes, L. A. Isabella, and T. C. MacAvoy(1998), "Alliance Management: A View from the Past and a Look to the Future," Journal of Management Studies, 35(6), 747-772.

Strang, R. A.(1976), "Sales Promotion-Fast 
Growth, Faulty Management," Harvard Business Review, July-August, 115-124. Strauss, A. and J. Corbin(1998), Basics of Qualitative Research: Techniques and Procedures for Developing Grounded Theory, Thousand Oaks, California: Stage Publications, Ltd.

Varadarajan, P. R.(1986), "Horizontal Cooperative Sales Promotion: A Framework for Classification and Additional Perspectives," Journal of Marketing, 50(April), 61-73.

Webster, Fredrick E.(1965), "The Deal

Prone Consumer," Journal of Marketing Research, 2(May), 186-189.

Wildman, L.(1998), "Alliances and

Networks: The Next Generation,"
International Journal of Technology Management, 15(1), 96-108.

Williamson, O. E.(1989), "Strategizing, Economizing, and Economic Organization," Strategic Management Journal, 12(2), 75-94.

Varadarajan, P. R.(2001), "Joint Sales Promotion: An Emerging Marketing Tool," Business Horizons, Sept-Oct, 43-49.

Young, J. A., F. W. Gillbert, and F. S. Mclntyre(1996), "An Investigation of Relationalism across a Range of Marketing Relationships and Alliance," Journal of Business Research, 35, 139-151. 


\title{
An Exploratory Study on Tie-in Promotion
}

\author{
Lee, Eun $\left.\mathrm{Mi}^{* 1}\right)$ \\ Park, Hyun $\mathrm{Hee}^{* *}$ \\ Jeon, Jung Ok***
}

\begin{abstract}
s
In today's market scenario, consumers are bombarded with similar promotional messages. It means that managers have to pay attention to promotion strategy to create strong effect as well as to break through the monotony. In this context, although there are strong needs concerning tie-in promotion, research investigating tie-in promotion is limited.

Therefore, we extracted tie-in promotion tools and defined the concept of each tie-in promotion tool by analyzing various tie-in promotion cases which are executed in current market. In addition, consumer's recognition of tie-in promotion was investigated through the in-depth interview.

The results of case analysis of tie-in promotion and in-depth interview are summarized as follows. First, 9 tie-in promotion tools were extracted: tie-in price reductions, tie-in coupons, tie-in membership, tie-in contests, tie-in premiums (tangibility, intangibility), tie-in payment terms, tie-in sample, tie-in event(culture event, charity event, experience event) and tie-in fund $\cdot$ rebate. Second, 3 categories of the recognition of the consumer for tie-in promotion were extracted: features of preferred tie-in promotion, expectation benefit of tie-in promotion, and risk factors of tie-in promotion. Especially, at the aspect of features of preferred tie-in promotion, fit between consumer pursuit benefit and tie-in promotion was found to be interesting. Moreover, the recognition of the consumer for tie-in promotion were divided with positive(preferred tie-in promotion features, expectation benefit of tie-in promotion) and negative(risk factors of tie-in promotion) factors.
\end{abstract}

In conclusion, the company's effort will be necessary to lower the perceived risk level occurring from the process of accomplishing the tie-in promotion strategy since consumers

* Ph.D. Candidate, Dept. of Business Administration, Graduate School, Pukyong National University

** BK21 Research Professor, School of Business Administration, Kyungpook National University

*** Professor, Div. of Business Administration, Pukyong National University(Corresponding Author) 
recognize both positive and negative effects of tie-in promotion.

Key words: tie-in promotion, tie-in promotion's tool, definitions of concept for tie-in promotion, consumer's recognition for tie-in promotion 